\title{
Diffuse Reflectance Spectroscopy Study of the Thermal Genesis and Molecular Structure of Chromium-Supported Catalysts
}

\author{
Bert M. Weckhuysen," An A. Verberckmoes, An L. Buttiens, and Robert A. Schoonheydt \\ Centrum voor Oppervlaktechemie en Katalyse, K. U. Leuven, Kardinaal Mercierlaan 92. \\ B-3001 Heverlee, Belgium
}

Received: May 20, 1993; In Final Form: September 14, 1993

\begin{abstract}
The diffuse reflectance spectra of a series of chromium-supported silica aluminas, with varying $\mathrm{SiO}_{2}$ content, have been investigated before and after drying and after calcination, successive $\mathrm{CO}$ reductions, and recalcination. The molecular structure of chromium before drying is influenced by the isoelectric point (IEP) of the supports. It is concluded that the lower the IEP of the support, the higher the amount of surface dichromate. After calcination at $720^{\circ} \mathrm{C}, \mathrm{Cr}$ is anchored to the surface without changing the chromate:dichromate ratio. Reduction results in the formation of octahedral $\mathrm{Cr}^{3+}$, pseudooctahedral and pseudotetrahedral $\mathrm{Cr}^{2+}$. A higher silica content of the support, a higher reduction temperature, and a higher calcination temperature result in a deeper reduction of the supported $\mathrm{Cr}$. Recalcination restores the initial chromate:dichromate ratio on each support; however, small quantities of $\mathrm{Cr}^{3+}$ remain in the samples. This deeper reduction and reversibility can be explained by the low $\mathrm{OH}$ content of the supports calcined at $720^{\circ} \mathrm{C}$.
\end{abstract}

\section{Introduction}

Chromium-supported catalysts are usually prepared by impregnation of a chromium salt onto the support, followed by drying and calcination. During the calcination procedure, the thermodynamically favoured reaction " $\mathrm{CrO}_{3} \rightleftharpoons 1 /{ }_{2} \mathrm{Cr}_{2} \mathrm{O}_{3}+3 / 2 \mathrm{O}_{2}$ " does not take place (or only to a small extent) in the presence of an oxide support. This phenomenon is generally explained by the anchoring of $\mathrm{Cr}$ onto the support (=stabilization). However, the molecular structure of the anchored $\mathrm{Cr}^{6+}$ species and the kind of interaction between $\mathrm{Cr}$ and the support are points of discussion in the literature.

The surface complex is considered to be chromate and/or dichromate, ${ }^{1-8}$ but also the presence of polychromates 9,10 and highly distorted monochromate ${ }^{11}$ is claimed. Several types of interactions of the surface complexes are proposed in the literature. Most investigations assume an esterification reaction between chromic acid and the hydroxyl groups of the supports, resulting in the formation of surface chromates and/or dichromates (and polychromates) $.1,4,8,12$ The exothermal peak in differential thermal analysis (DTA) curves of Cr-supported catalysts around $250^{\circ} \mathrm{C}$ is ascribed to this reaction. ${ }^{8}$ Additional evidence comes from infrared (IR) investigations, indicating a consumption of $\mathrm{OH}$ groups by depositing $\mathrm{Cr}$ on the support. ${ }^{3}$ This $\mathrm{OH}$ consumption is proportional to the quantity of deposited $\mathrm{Cr}$. Recently, Turek et al. have shown that on $\mathrm{Al}_{2} \mathrm{O}_{3}$ this $\mathrm{OH}$ consumption starts from the more basic $\mathrm{OH}$ groups to the more acidic groups, indicating an acid-base type reaction. ${ }^{13} \mathrm{McDaniel}$ has followed the reaction between $\mathrm{CrO}_{2} \mathrm{Cl}_{2}$ and silica, observing the release of $\mathrm{HCl},{ }^{1,5} \mathrm{This}$ can be explained only by the reaction of surface hydroxyls with the Cr precursor.

A similar reaction between $\mathrm{CrO}_{3}$ and the support is envisaged by Wittgen et al., ${ }^{14}$ Ellison et al., ${ }^{15}$ I wasawa et al., ${ }^{16}$ and Hogan. ${ }^{17}$ In accordance with Turek et al.,13 Ellison et al. ${ }^{15}$ and Fubini et al. ${ }^{18}$ suggest a decondensation of the polyanions, followed by chemisorption of the monomeric species, while Bhutani et al. ${ }^{19}$ suggest a ligand-exchange reaction between $\mathrm{Cr}$ and $\mathrm{Sb}_{2} \mathrm{O}_{3}$.

In a previous study we have reported the quantification of $\mathrm{Cr}^{2+}, \mathrm{Cr}^{3+}$, and $\mathrm{Cr}^{6+}$ by diffuse reflectance spectrocopy (DRS) after calcination at $550^{\circ} \mathrm{C}$, successive $\mathrm{CO}$ reductions and recalcination. ${ }^{2}$ On the calcined catalysts chromate and dichro-

- To whom correspondence should be addressed.

- Abstract published in Advance ACS Abstracts, December 15, 1993.
TABLE 1: Characteristics of the Supports

\begin{tabular}{cccc}
\hline $\begin{array}{c}\text { SA- } n \\
\text { with } n=\end{array}$ & $\begin{array}{c}\text { BET surface } \\
\text { area }\left(\mathrm{m}^{2} / \mathrm{g}\right)\end{array}$ & $\begin{array}{c}\text { pore vol } \\
(\mathrm{mL} / \mathrm{g})\end{array}$ & $\begin{array}{c}\text { pore size } \\
(\mathrm{nm})\end{array}$ \\
\hline 0 & 365 & 2.0 & $3-9$ \\
20 & 337 & 1.7 & $1.5-8$ \\
40 & 329 & 1.4 & $1.5-7$ \\
60 & 253 & 1.0 & $1.5-10$ \\
100 & 735 & 0.8 & $1-3$
\end{tabular}

mate are present with traces of $\mathrm{Cr}^{5+}$. The dichromate:chromate ratio is the highest for silica, zero for alumina, and in between for silica alumina. After reduction three new species were formed: octahedral $\mathrm{Cr}^{3+}$, pseudooctahedral $\mathrm{Cr}^{2+}$ and pseudotetrahedral $\mathrm{Cr}^{2+}$. On alumina only octahedral $\mathrm{Cr}^{3+}$ and small portions of octahedral $\mathrm{Cr}^{2+}$ were observed, while on silica and silica alumina the $\mathrm{Cr}^{2+}: \mathrm{Cr}^{3+}$ ratio increases with the silica content.

In this work three subjects will be studied systematically: (1) the interaction between $\mathrm{Cr}$ and the support before and after drying, after calcination and after rehydration; (2) the influence of the $\mathrm{SiO}_{2}: \mathrm{Al}_{2} \mathrm{O}_{3}$ ratio of the amorphous supports on the molecular structure of supported $\mathrm{Cr}$ after calcination; (3) the influence of a high-temperature calcination $\left(720^{\circ} \mathrm{C}\right.$ ) and the $\mathrm{SiO}_{2}: \mathrm{Al}_{2} \mathrm{O}_{3}$ ratio of the amorphous supports on the speciation of reduced and recalcined $\mathrm{Cr}$.

\section{Experimental Section}

Sample Preparation and Characterization. Preparation. A series of $\mathrm{SiO}_{2} \cdot \mathrm{Al}_{2} \mathrm{O}_{3}$ was prepared following a modified method of Chen et al. ${ }^{21}$ They are indicated as SA- $n$, where $n$ is the weight percentage of $\mathrm{SiO}_{2}$. The appropriate amounts of tetraethylorthosilicate (TEOS) and aluminum triisopropoxide (Al$(i \mathrm{P})_{3}$ ) were mixed in $128 \mathrm{~mL}$ of ethanol during $30 \mathrm{~min}$ at room temperature. After addition of $35 \mathrm{~mL}$ of $1 \mathrm{M} \mathrm{HCl}$, the acid hydrolysis started and the suspension was mixed for $1 \mathrm{~h}$. The resulting gel was dried at $60^{\circ} \mathrm{C}$ and $100^{\circ} \mathrm{C}$ for $8 \mathrm{~h}$ and calcined at $550^{\circ} \mathrm{C}$ for $16 \mathrm{~h}$. The obtained samples were crushed. $\mathrm{SiO}_{2}$ was prepared following a procedure described previously. ${ }^{2}$ The $\mathrm{Cr}$ catalysts were prepared by the incipient wetness method with chromium(VI) oxide $\left(\mathrm{CrO}_{3}\right)$. The chromium loading was $0.2 \mathrm{wt}$ $\%$.

Characterization. The characteristics of the supports were measured by dynamic $\mathbf{N}_{2}$ adsorption on an Omnisorp 100 (Coulter), after pretreatment in vacuum at $200^{\circ} \mathrm{C}$ for $8 \mathrm{~h}$. These characteristics are given in Table 1. 